\title{
Primary Cutaneous Chrysosporium Infection following Ear Piercing: A Case Report
}

\author{
Poonkiat Suchonwanit Chayada Chaiyabutr Vasanop Vachiramon \\ Division of Dermatology, Faculty of Medicine, Ramathibodi Hospital, Mahidol University, \\ Bangkok, Thailand
}

\section{Key Words}

Chrysosporium infection $\cdot$ Ear piercing $\cdot$ Hyalohyphomycosis

\begin{abstract}
Chrysosporium is a large genus of saprophytic fungi that is commonly found in the soil. Infection caused by this organism is rare in humans and typically occurs in immunocompromised patients. Primary cutaneous Chrysosporium infection is relatively rare and has been reported in a heart transplant patient. The prognosis is usually favorable, but very poor in the setting of persistent profound immunosuppression. We herein report a case of primary cutaneous Chrysosporium infection following ear piercing in an immunocompetent patient. It is important for clinicians to consider this condition in patients with slow-onset skin and soft tissue infection following cutaneous injury, even in an immunocompetent setting.
\end{abstract}

(C) 2015 S. Karger AG, Basel

\section{Introduction}

Chrysosporium is a large genus of saprophytic fungi that is commonly found in the soil [1]. Chrysosporium infection is relatively rare in humans and typically occurs in immunocompromised hosts. We herein report a case of primary cutaneous Chrysosporium infection following ear piercing in an immunocompetent patient.

KARGER 125:s $\quad \begin{aligned} & \text { Vasanop Vachiramon, MD } \\ & \text { Division of Dermatology, Faculty of Medicine } \\ & \text { Ramathibodi Hospital, Mahidol University } \\ & \text { 270 Rama VI Road, Rajthevi, Bangkok } 10400 \text { (Thailand) } \\ & \text { E-Mail vasanop@gmail.com }\end{aligned}$


Case Reports in
Dermatology

\begin{tabular}{l|l}
\hline \multicolumn{2}{l}{ Case Rep Dermatol 2015;7:136-140 } \\
\hline DOI: 10.1159/000436989 & $\begin{array}{l}\text { ○ 2015 S. Karger AG, Basel } \\
\text { www.karger.com/cde }\end{array}$ \\
\hline
\end{tabular}

Suchonwanit et al.: Primary Cutaneous Chrysosporium Infection following Ear Piercing: A Case Report

\section{Case Report}

A 25-year-old healthy woman presented with a 2-year history of an itchy erythematous plaque on the right ear pinna. She had no fever, weight loss or other systemic symptoms. The patient had been treated with oral cephalexin, ciprofloxacin and anti-tuberculous agents without improvement. She had had her right ear pierced by a beautician 8 months before the lesion developed. Skin examination revealed ill-defined scaly erythematous and slightly edematous plaque, with small nodules on the rim of the right ear pinna and preauricular area (fig. 1). There was no lymphadenopathy. The results of the rest of the physical examinations were normal. Laboratory investigations, including routine blood tests, liver and renal functions, and chest radiography were all within normal limits. HIV antibody testing was negative.

A punch biopsy was performed from the right preauricular area. Histological examination demonstrated superficial and deep perivascular and nodular inflammatory cell infiltration admixed with lymphocytes, histiocytes, plasma cells and multinucleated giant cells forming small foci of granuloma (fig. 2a). Non-pigmented septate hyphae were also seen within the granuloma (fig. 2b). Periodic acid-Schiff stain highlighted fungal hyphae (fig. 2c). The histological finding and laboratory investigations suggested a diagnosis of cutaneous hyalohyphomycosis. Polymerase chain reaction was performed on the colony sample using the gene fragment, and BLASTN search against the GenBank database revealed a 98\% nucleotide sequence identity to Chrysosporium spp.

Based on the above findings, we diagnosed the patient as primary cutaneous hyalohyphomycosis from Chrysosporium spp. She was treated with oral itraconazole $200 \mathrm{mg}$ per day, which resulted in mild improvement of the dermatosis. Therefore, the serum itraconazole trough level, which was measured just before the next dose administration, was investigated. Using a high-performance liquid chromatography (HPLC) assay, the itraconazole trough level in this patient was $0.118 \mu \mathrm{g} / \mathrm{ml}$, which is not enough for the therapeutic concentration for localized infection $(>0.5 \mu \mathrm{g} / \mathrm{ml})[2,3]$. The dose was adjusted to $400 \mathrm{mg}$ per day and the drug trough level after 7 days of administration was $0.572 \mu \mathrm{g} / \mathrm{ml}$, showing dramatic improvement. The treatment was continued for a total of 8 months. No recurrence was observed during a 3-month follow-up after treatment had been discontinued.

\section{Discussion}

Hyalohyphomycosis is the term used to represent infections caused by colorless septate fungal hyphae in infected tissue [4]. The organisms causing hyalohyphomycosis include members of the Fusarium, Penicillium, Scedosporium, Acremonium, Paecilomyces, Aspergillus, Scopulariopsis, Basidiomycota, Schizophyllum commune, Beauvaria, Trichoderma, Chaectoconidium, Chrysosporium and Microascus genera [5].

Chrysosporium is commonly found in the soil. Although Chrysosporium is usually a contaminant, its presence in cultures and histological sections is evidence of pathogenicity. Chrysosporium infection mostly affects the lungs, but dissemination to the brain, sinus, skin, bone, heart, liver and kidney has been reported especially in immunocompromised patients, such as those undergoing transplantation or patients with diabetes or AIDS [1]. Localized infections, such as keratomycosis or osteomyelitis, may also occur in healthy individuals [6, 7]. Primary cutaneous Chrysosporium infection is relatively rare. It has been reported in a heart transplant patient who presented with a scaly erythematous, multinodular lesion above the right knee with a history of trauma during a camping trip [8]. The 
Suchonwanit et al.: Primary Cutaneous Chrysosporium Infection following Ear Piercing: A Case Report

prognosis is usually favorable, but very poor in the setting of persistent profound immunosuppression [1].

In vitro susceptibility data for Chrysosporium spp. are limited, and minimum inhibitory concentration data are available only for some strains of Chrysosporium zonatum. Amphotericin $B$ is the most active drug whereas itraconazole susceptibility is strain-dependent. Fluconazole and 5-fluorocytosine are not active [9]. Therefore, it is essential to follow up the clinical response and determine in vivo drug concentration. For itraconazole, it is advisable to evaluate the drug trough level in all patients early in the course of treatment (4-7 days), in patients with evidence of clinical failure, or following the initiation of any drug demonstrated to alter itraconazole metabolism. Using a HPLC assay, the itraconazole trough concentration for localized infection should be $\geq 0.5 \mu \mathrm{g} / \mathrm{ml}$ and $>1 \mu \mathrm{g} / \mathrm{ml}$ in the case of treatment of systemic fungal infection $[2,3]$.

In conclusion, we herein present a case of primary cutaneous Chrysosporium infection following ear piercing. It is important for clinicians to consider this condition in patients with slow-onset skin and soft tissue infection following cutaneous injury, particularly if they do not respond to conventional antibiotic treatment, even in an immunocompetent setting. In addition, the serum itraconazole trough level should be evaluated after administration for 4-7 days or in patients with poor clinical response, which may occur from individual pharmacokinetic variability.

\section{Acknowledgement}

We thank Dr. Piriyaporn Chongtrakool for valuable support concerning laboratory service.

\section{Statement of Ethics}

We state that our patient gave informed consent. The research complies with all ethical guidelines for human studies.

\section{Disclosure Statement}

The authors make no financial disclosure. There was no funding or support.

\section{References}

1 Anstead GM, Sutton DA, Graybill JR: Adiaspiromycosis causing respiratory failure and a review of human infections due to Emmonsia and Chrysosporium spp. J Clin Microbiol 2012;50:1346-1354.

$\longrightarrow 2$ Andes D, Pascual A, Marchetti O: Antifungal therapeutic drug monitoring: established and emerging indications. Antimicrob Agents Chemother 2009;53:24-34.

3 The University of Iowa, Department of Pathology: Itraconazole drug level; in: Laboratory Services Handbook (update June 18 2013; cited January 29 2013). Available at: https://www.healthcare.uiowa.edu/ path_handbook/handbook/test1168.html.

4 Walsh TJ, Groll A, Hiemenz J, Fleming R, Roilides E, Anaissie E: Infections due to emerging and uncommon medically important fungal pathogens. Clin Microbiol Infect 2004;10:48-66.

5 Anaissie EJ: Hyalohyphomycosis; in Anaissie EJ, McGinnis MR, Pfaller MA (eds): Clinical Mycology, ed 2. New York, Churchill Livingstone, 2009, p 313.

6 Wagoner MD, Badr IA, Hidayat AA: Chrysosporium parvum keratomycosis. Cornea 1999;18:616-620. 
Suchonwanit et al.: Primary Cutaneous Chrysosporium Infection following Ear Piercing: A Case Report

7 Stillwell WT, Rubin BD, Axelrod JL: Chrysosporium, a new causative agent in osteomyelitis. A case report. Clin Orthop Relat Res 1984;184:190-192.

-8 Stebbins WG, Krishtul A, Bottone EJ, Phelps R, Cohen S: Cutaneous adiaspiromycosis: a distinct dermatologic entity associated with Chrysosporium species. J Am Acad Dermatol 2004;51(5 suppl):S185-S189.

-9 Roilides E, Sigler L, Bibashi E, Katsifa H, Flaris N, Panteliadis C: Disseminated infection due to Chrysosporium zonatum in a patient with chronic granulomatous disease and review of non-Aspergillus fungal infections in patients with this disease. J Clin Microbiol 1999;37:18-25.

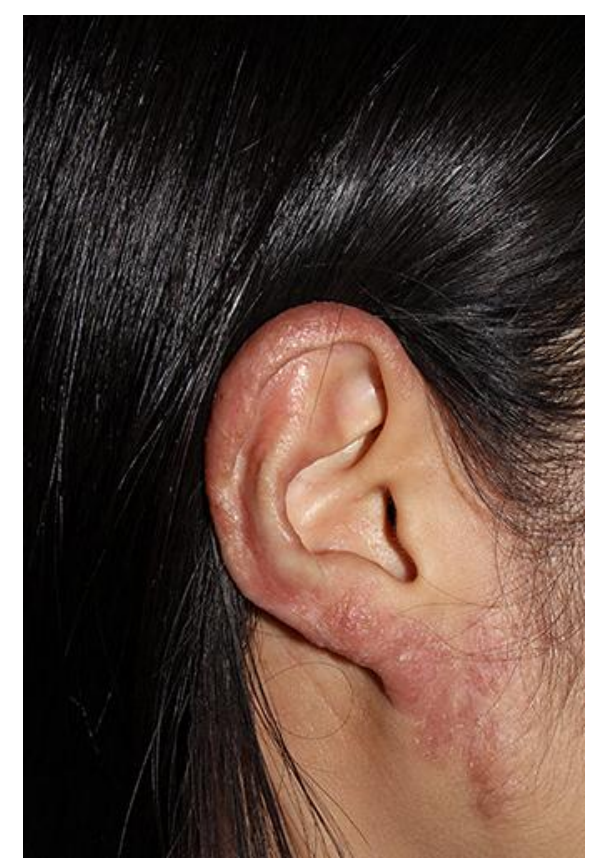

Fig. 1. Erythematous, slightly edematous plaque and small nodules on the right ear pinna. 


\section{Case Reports in Dermatology}

\begin{tabular}{l|l}
\hline DOI: $10.1159 / 000436989$ & $\begin{array}{l}\text { ○ } 2015 \text { S. Karger AG, Basel } \\
\text { www.karger.com/cde }\end{array}$ \\
\hline
\end{tabular}

Suchonwanit et al.: Primary Cutaneous Chrysosporium Infection following Ear Piercing A Case Report
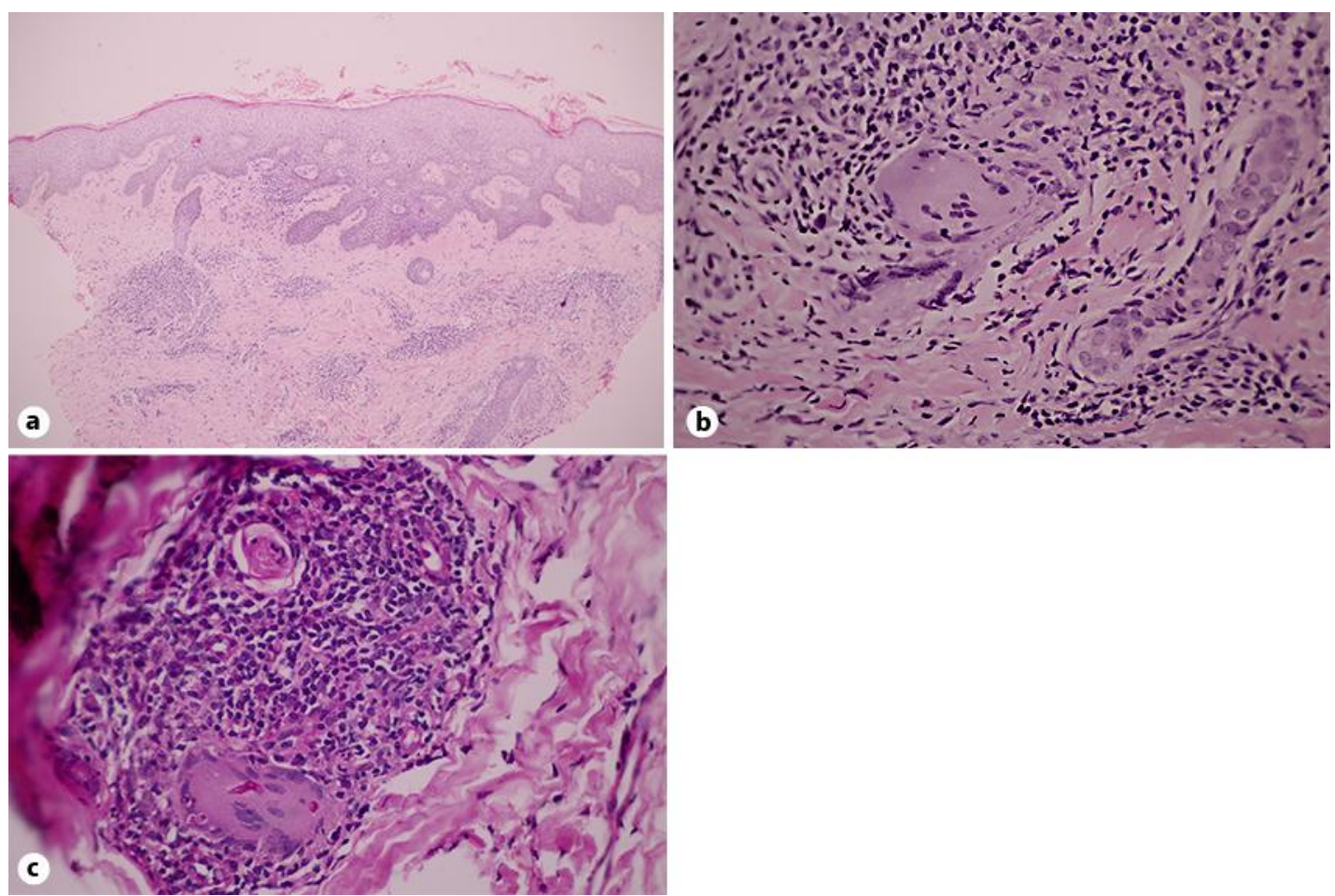

Fig. 2. a Histology showing superficial and deep perivascular and nodular inflammatory cell infiltration $(H E, \times 100)$. b Non-pigmented septate hyphae within the granuloma $(H E, \times 600)$. c Periodic acid-Schiff stain highlighting the fungal hyphae $(\times 600)$. 